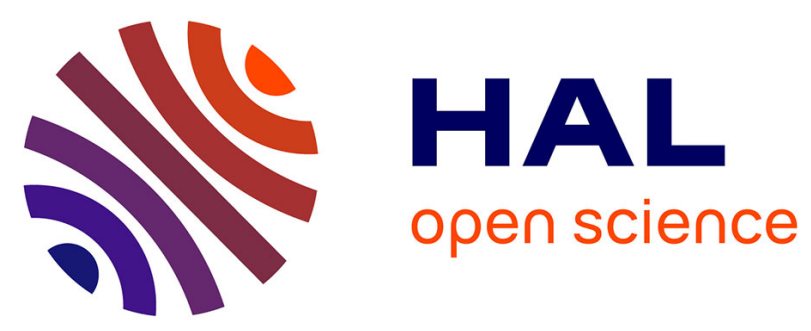

\title{
Electrical Characterization of Textile-Based Enzymatic Biofuel Cell for Energy Harvesting Interface Circuit
}

\author{
Seonho Seok, Elie Lefeuvre, Cong Wang, Jungyul Park
}

\section{To cite this version:}

Seonho Seok, Elie Lefeuvre, Cong Wang, Jungyul Park. Electrical Characterization of TextileBased Enzymatic Biofuel Cell for Energy Harvesting Interface Circuit. 2019 Symposium on Design, Test, Integration \& Packaging of MEMS and MOEMS (DTIP), May 2019, Paris, France. 10.1109/DTIP.2019.8752787 . hal-02373499

\section{HAL Id: hal-02373499 \\ https://hal.science/hal-02373499}

Submitted on 21 Nov 2019

HAL is a multi-disciplinary open access archive for the deposit and dissemination of scientific research documents, whether they are published or not. The documents may come from teaching and research institutions in France or abroad, or from public or private research centers.
L'archive ouverte pluridisciplinaire HAL, est destinée au dépôt et à la diffusion de documents scientifiques de niveau recherche, publiés ou non, émanant des établissements d'enseignement et de recherche français ou étrangers, des laboratoires publics ou privés. 


\title{
Electrical Characterization of Textile-Based Enzymatic Biofuel Cell for Energy Harvesting Interface Circuit
}

\author{
Seonho Seok ${ }^{1}$, Elie Lefeuvre ${ }^{1}$, Cong Wang ${ }^{2}$, and Jungyul Park ${ }^{2}$ \\ Center for Nanoscience and Nanotechnology (C2N), University-Paris-Saclay, Palaiseau, France ${ }^{1}$ \\ Department of Mechanical Engineering, Sogang University, Mapo-gu, Seoul, Republic of Korea ${ }^{2}$ \\ Email: seonho.seok@u-psud.fr
}

\begin{abstract}
This paper presents electrical characterization and power management circuit of textile-based enzymatic biofuel cell. Firstly, static electrical characteristics (open circuit voltage, short circuit current, and maximum power) of the enzymatic biofuel cell have been investigated by imposing a voltage across the biofuel cell and measuring corresponding output current. Output power of the biofuel cell has been characterized as a function of load resistance, while a glucose solution of $100 \mathrm{mM}$ is fed from one end of the textile-based biofuel cell. Two-step approach based on supercapacitor and DC-DC converter has been proposed and tested as power management of the proposed biofuel cell.
\end{abstract}

Keywords-Textile-based glucose fuel cell, energy harvesting, DC-DC converter, power management

\section{INTRODUCTION}

Wearable devices have gained significant interest from academia and industry owing to their immense applications such as biomedical, health and entertainment etc [1, 2]. To realize the internet of things (IoT) for human body data or human-machine interactions, wearable devices need to be capable of undertaking multiple complex tasks and requires long term and sustainable energy sources.

To address the above issues, the wearable power supply needs to be developed, which enables to generate electric power from body fluid for sustainable working [3, 4]. Here, a wearable textile-based glucose fuel cell is proposed using moisture management fabrics (MMF) for improved and long-term power generation as shown in Fig. 1. MMF is widely used as basic materials for a sportswear and shows very fast sweat absorption and water evaporation. It is composed of polyester with modified cross-sectional shapes for quick water absorbing and wicking, and has the series of closely spaced channels for high evaporation. The balance between fast water evaporation and absorption enables high flow rate and continuous flow within MMF. Owing to low-cost and scalable fabrication process, it can be easily integrated into clothes, socks or underwear to utilize the human body fluid like sweat, tear or urine as fuel resource to generate energy for wearable devices. The role of power management circuit for energy harvesters is critical for delivering maximum power from energy harvesters to energy storage element, for example, battery. Basically, it is achieved by matching load resistance with the internal resistance (or impedance) of the energy harvesters in many energy harvesters. Different approaches have been reported to achieve high- efficiency energy harvesters [5-7]. Direct powering of low power electronics with a biofuel cell may be undesirable due to its low output voltage and load dependent characteristics [8]. Thus, a DC-DC converter is need as an interface circuit between biofuel cell and low power electronics. Due to low energy of biofuel cell energy harvester, multiple fuel cell element interconnected, for example, microbial fuel cell (MFC), is frequently used to increase output voltage as well as power capacity [9]. In this case, two-staged DC-DC converter could be used to achieve maximal energy harvesting; the first converter harvests the energy from an MFC and charges the storage capacitor, and the second layer converter boosts the voltage to an appropriate level for the connected load [9]. In this paper, preliminary test results of a two-staged power management of a textile-based biofuel cell is presented.

\section{TEXTILE-BASED ENZAYMATIC BIOFUEL CELL}

The textile-based glucose fuel cell consists of MMF, carbon cloth-based cathode and anode, and conductive thread as shown Fig. 1 (a). As depicted in Fig. 1 (b), the cathode and anode were fabricated by coating carbon cloth with Prussian blue (PB) nanoparticles and glucose oxidase (GOD), respectively. Especially, the carbon cloth for the cathode is treated with $30 \%$ PTFE to enable the air exchange within the cathode for longterm use. MMF in the middle is designed as channels with hydrophobic boundary for fuel resource absorption and transport. The conductive thread is used as a current collector to connect with the external loads.

When $100 \mathrm{mM}$ glucose in PBS solution was introduced into the chamber shown in Fig. 3 (a), the glucose fuel cell started to absorb the solution through MMF layer and guided it into the reaction region where $\mathrm{PB}$ and GOD electrodes existed. Subsequently, the voltage signal and current signal were recorded by a computer connected to picoammeter/voltage source through GPIB card using Labview program. To analyze the I-V curve, the electrical characteristics of the glucose fuel cell including the open circuit voltage, the short circuit current and the maximum power were obtained.

Fig. 2 shows static electrical characteristics of the enzymatic biofuel cell. Open circuit voltage $\left(\mathrm{V}_{\mathrm{oc}}\right)$, short circuit current $\left(\mathrm{I}_{\mathrm{sc}}\right)$ and maximum output power have been extracted from the curves; $\mathrm{V}_{\mathrm{oc}}=0.3 \mathrm{~V}, \mathrm{I}_{\mathrm{sc}}=200 \mu \mathrm{A}$ and $\mathrm{P}_{\max }=12 \mu \mathrm{W} / \mathrm{cm}^{2}$ for the 
best case, $\mathrm{V}_{\mathrm{oc}}=0.24 \mathrm{~V}, \mathrm{I}_{\mathrm{sc}}=60 \mu \mathrm{A}$ and $\mathrm{P}_{\max }=3 \mu \mathrm{W} / \mathrm{cm}^{2}$ for the worst case.

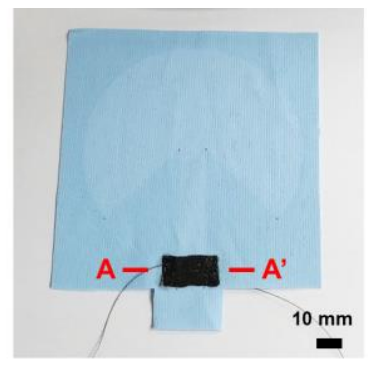

(a)

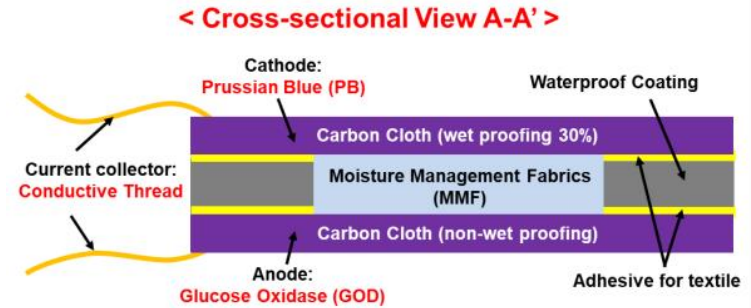

(b)

Fig. 1 Textile-based biofuel cell

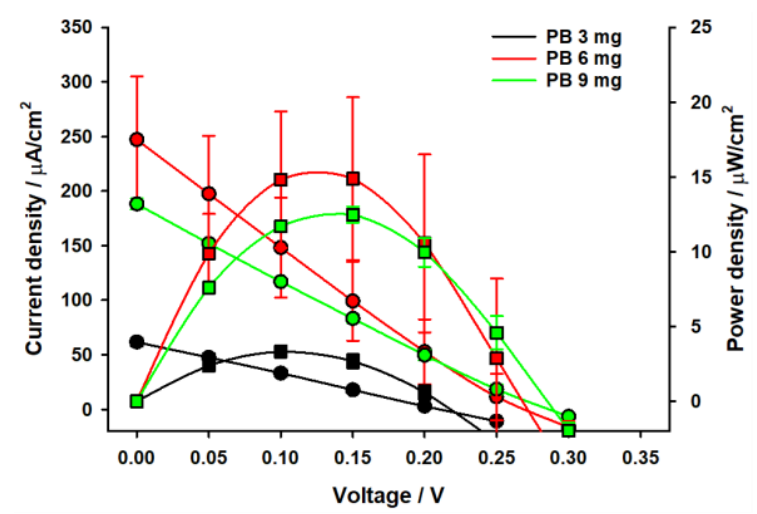

Fig. 2 Static electrical characteristics of the proposed enzymatic biofuel cell

\section{ELECTRICAL CHRACTERIZATION OF BIOFUEL CELL}

First of all, output power of the biofuel cell has been characterized as a function of load resistance, while a glucose solution of $100 \mathrm{mM}$ is fed from one end of the textile-based biofuel cell as depicted in Fig. 3. The output power has been measured up to 30 minutes at a step of 15 minutes and the optimal load resistance value is found around $100 \mathrm{k} \Omega$. Given with the optimal load resistance, maximum output power is about $0.3 \mu \mathrm{W} / \mathrm{cm}^{2}$. Note that the output power has increased until 30 minutes after starting the measurement and the electrode (black color in the figure) size is $1 \mathrm{~cm}^{2}$.

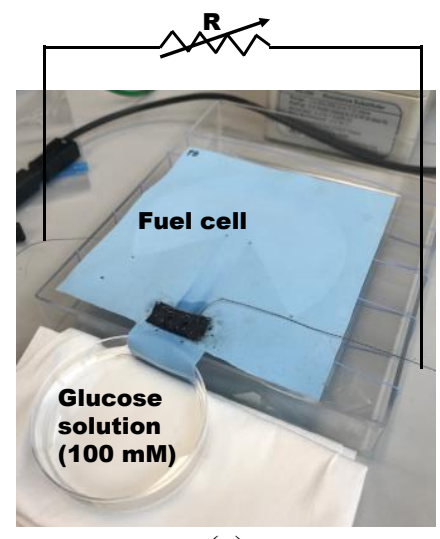

(a)

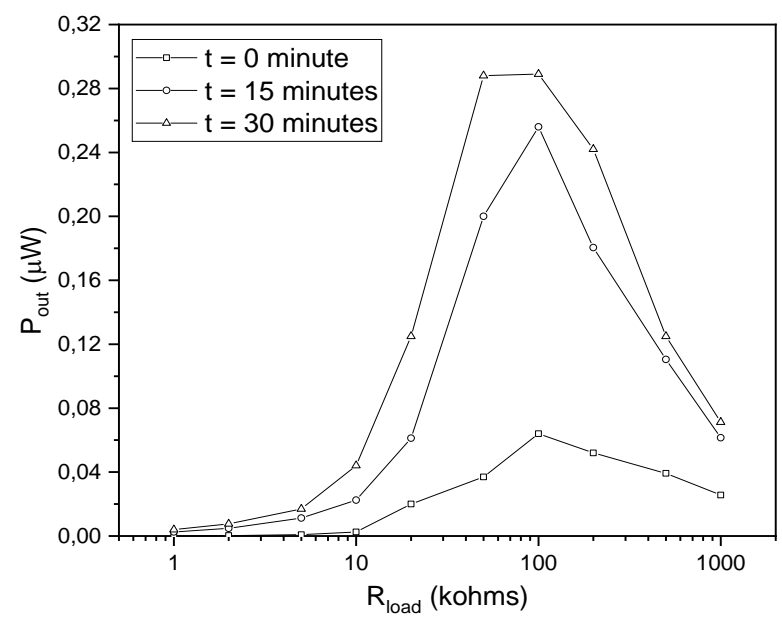

(b)

Fig. 3 Electrical characterization of the biofuel cell

As the harvested power is not large, another sample with lager electrode has been tested, while a wind of $0.8 \mathrm{~m} / \mathrm{s}$ is applied onto the biofuel cell. The wind plays a role of accelerating of liquid evaporation and thus preventing the channel from being saturated by the glucose solution. This $0.8 \mathrm{~m} / \mathrm{s}$ wind speed corresponds to slow walking speed of human (the average is about $1.4 \mathrm{~m} / \mathrm{s}$ [10]). In the same way as the previous one, the output power has been measured as shown in Fig. 4. Interestingly, the biofuel cell with larger electrode shows higher power output than the previous one, $1.4 \mu \mathrm{W} / \mathrm{cm}^{2}$ with an optimal resistance of $2 \mathrm{k} \Omega$. After that, dynamic electrical characteristic of the biofuel cell is also characterized as presented in Fig. 5. The output voltage needs stabilization time of about 100 seconds when the load resistance is changed from $200 \mathrm{k} \Omega$ to $100 \mathrm{k} \Omega$. This dynamic response will be useful to determine capacitance value of electrical circuit model of the biofuel cell. 


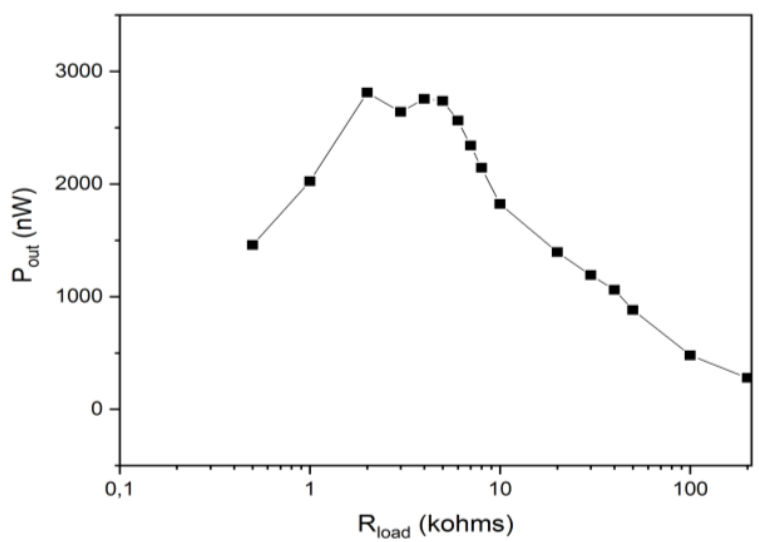

Fig. 4 Output power vs. $\mathrm{R}_{\text {load }}$ with larger electrode

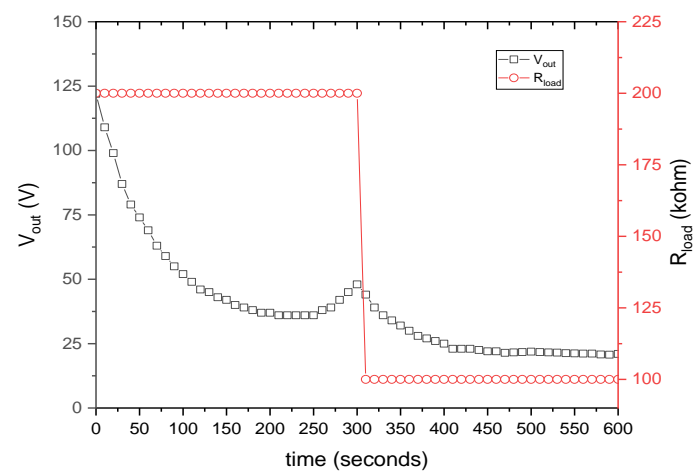

Fig. 5 Dynamic response of the biofuel cell

Due to small output power of the biofuel cell, a supercapacitor has been used as an intermediate element between the biofuel cell and DC-DC converter. The approach converting the energy generated by the biofuel cell is that it is first stored in a supercapacitor and then it is fed into DC-DC converter for power management. Hence, a supercapacitor of $220 \mathrm{mF}$ is directly connected with the biofuel cell to find charging characteristic as a function of charging time as shown in Fig. 6. Charging time to reach $\mathrm{V}_{\text {supercap }}=100 \mathrm{mV}$ is 40 minutes after which DC-DC conversion can be started.

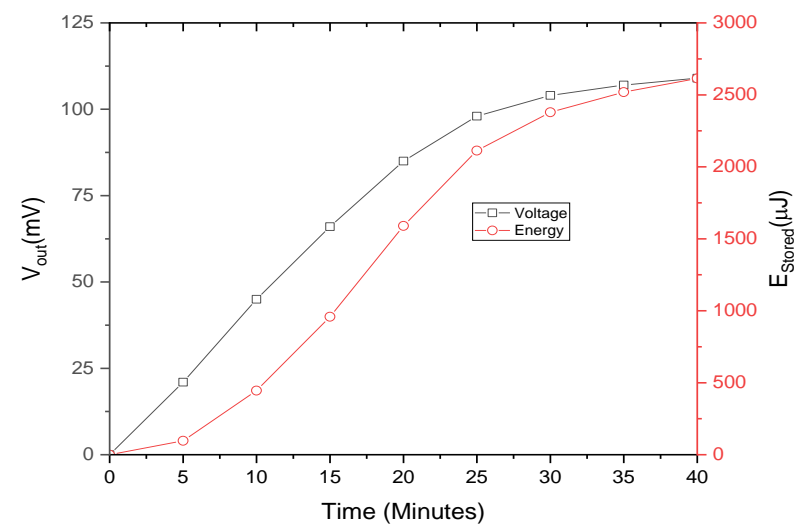

Fig. 6 Evolution of output voltage and energy stored at $0.22 \mathrm{~F}$ supercapacitor

A Buck-boost DC-DC converter is then connected with the supercapacitor after it is charged up to $100 \mathrm{mV}$ as shown in Fig.
7. The DC-DC converter is used to step up the supercapacitor voltage suitable for conventional battery. Energy stored at the supercapacitor is converted through inductor L1 and diode D before it is charged into output capacitor $\mathrm{C} 1$ by adjusting duty cycle of clock control signal of switch. Evolution of the voltage on supercapacitor and $\mathrm{C} 1$ at different conditions is presented in Fig. 8. Output voltage is ranged from $2.5 \mathrm{~V}$ to $4 \mathrm{~V}$ and conversion time (i.e. time needed to extract more than $90 \%$ of the energy stored in the supercapacitor) is around one minute for all of cases.

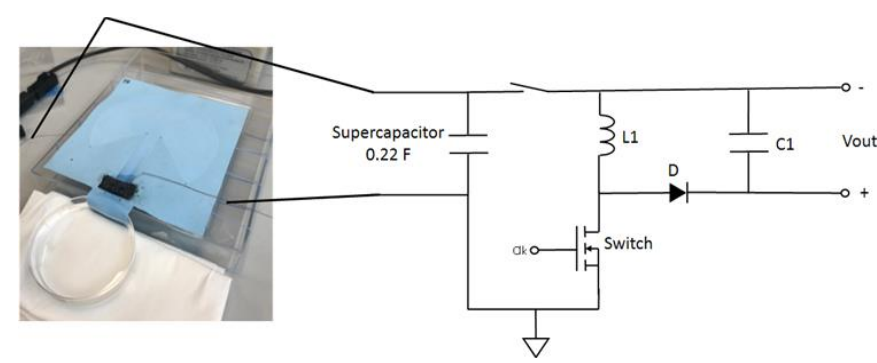

Fig. 7 Overall energy conversion circuit of the biofuel cell

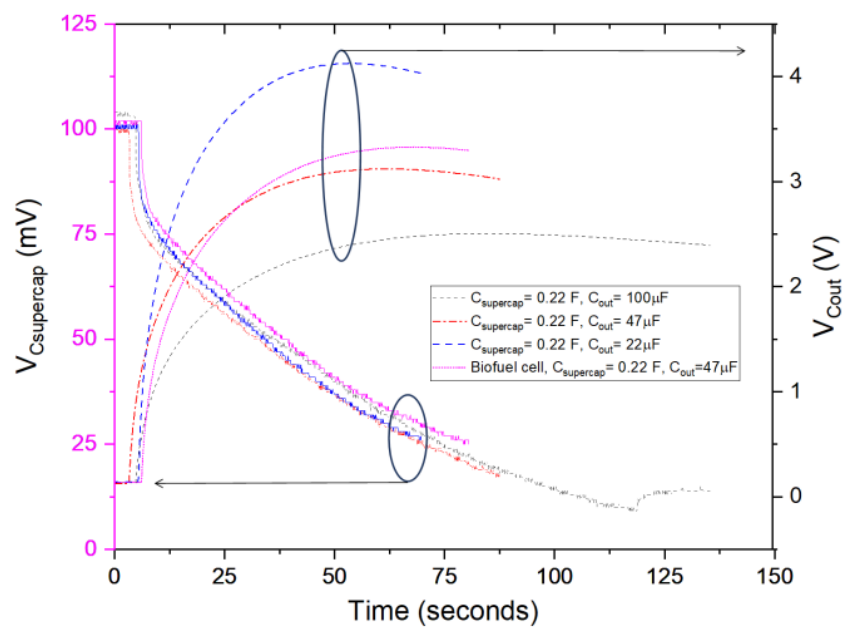

Fig. 8 Evolution of supercapacitor voltage and output voltage due to DC-DC conversion 


\section{CONCLUSION}

Textile-based enzymatic biofuel cell has been electrically characterized and combined with power management circuit as a wearable energy source. The biofuel cell shows electrode-size dependent internal impedance, which is a critical parameter for efficient power transfer. A two-step power management circuit, composed of a DC-DC converter combined with an intermediate supercapacitor, has been successfully demonstrated. This circuit enables to increase the output voltage, making thus possible to power various electronic devices with the harvested energy.

\section{REFERENCES}

[1] W. Jia, X. Wang, S. Imani, A. J. Bandodkar, J. Ramirez, P. P. Mercier and J. Wang, "Wearable textile biofuel cells for powering electronics", Journal of Materials Chemistry A, Vol. 2, 2014, pp. 18184-18189.

[2] F. Yi, H. Ren, J. Shan, X. Sun, D. Wei and Z. Liu, " Wearable energy sources based on 2D materials", Chemical Society Reviews, Vol. 47, No. 9, 2018, pp. 3152-3188

[3] H.-K. Chang, E. Choi and J. Park, "Paper-based energy harvesting from salinity gradients", Lab on a Chip, Vol. 6, pp. 700-708, 2016.
[4] S. Pang, Y. Gao and S. Choi, "Flexible and stretchable biobatteries: monolithic integration of membrane-free microbial fuel cells in a single textile layer", Advanced Energy Materials, 2017, pp. 1702261.

[5] G. K. Ottman, et al, "Adaptive Piezoelectric Energy Harvesting Circuit for Wireless Remote Power Supply”, IEEE Transactions on Power Electronics, Vol. 17, Sept. 2002, pp. 669 - 676.

[6] Y. K. Ramadass, et al, "An Efficient Piezoelectric Energy Harvesting Interface Circuit Using a Bias-Flip Rectifier and Shared Inductor", IEEE Journal of Solid-State Circuts, Vol.45, No.1, Jan 2010, pp.189 - 204.

[7] Elie Lefeuvre, Adrien Badel, Alexis Brenes, Seonho Seok, Chan-Sei Yoo, "Power and frequency bandwidth improvement of piezoelectric energy harvesting devices using phase-shifted SECE interface circuit", Journal of Intelligent Material Systems and Structures, 2017.

[8] X. Zhang, et al, "A High-Efficiency DC-DC Boost Converter for a Miniaturized Microbial Fuel Cell", IEEE Transactions on Power Electronics, Vol. 30, No. 4, April 2015, pp. 2041 - 49.

[9] J. Park et al, "Efficient Energy Harvester for Microbial Fuel Cells using DC/DC Converters", IEEE Energy Conversion Congress and Exposition, Sep. 2011.

[10] R. C. Browning, E. A. Baker, J. A. Herron and R. Kram, "Effects of obesity and sex on the energetic cost and preferred speed of walking," Journal of Applied Physiology, 2006, vol.100, pp.390-398 